\title{
Neurogenic Differentiation Potential of Human Nasal Mucosa Obtained from the Middle and Inferior Turbinates
}

(Potensi Pembezaan Neurogen Mukosa Hidung Manusia Diperoleh daripada Turbinat Tengah dan Inferior)

\author{
TAN SHi NeE, YogeSWARAN LOKANATHAN, RoHAINA CHE MAN, \\ AMINUDDIN SAIM \& RUSZYMAH BT HJ IDRUS*
}

\begin{abstract}
Olfactory bulb and nasal mucosa are one of the sources for neural stem cell, including the superior and middle turbinates $(M T)$. The middle and inferior turbinates (IT) provides the largest area of nasal mucosa which is technically easier to harvest the stem cell for future transplantation. The ability of nasal respiratory epithelial cells (RECS) and nasal fibroblasts (NFS) from both middle and inferior turbinates to differentiate into neural lineage (NL) cells were compared in this study. Six redundant human MT and IT from post-sinus surgery were digested and cultured. The RECs and NFs were separated and induced with neurotrophic factors offorskolin, human basic fibroblast growth factor $(b F G F)$, platelet-derived growth factor-AA (PDGF-AA) and heregulin- $\beta 1$-EGF-domain. Based on immunocytochemistry and quantitative PCR, the NL induced NFs of MT expressed GFAP, Nestin and P75 receptor. NL induced RECs from MT and IT expressed GFAP and Nestin but did not express the P75 receptor protein. Regarding the control, the non-induced RECs and fibroblasts expressed Nestin only. This study demonstrated that nasal mucosa cells from both IT and MT have the potential to differentiate into neural lineage cells even though the fibroblasts of MT are superior in term of quality. Hopefully, these tissues will provide better donor area with less morbidity for autologous or allograft transplantation in future neural regenerative medicine.
\end{abstract}

Keywords: Nasal epithelial cells; nasal mucosa; neural induction; neural lineage; turbinate

ABSTRAK

Salah satu sumber sel stem saraf adalah bebuli olfaktori dan mukosa hidung, terutamanya dalam turbinat superior dan tengah (MT). Walau bagaimanapun, turbinat tengah dan turbinat inferior (IT) menyediakan kawasan terbesar untuk mukosa hidung dan secara teknikal, lebih mudah untuk memperoleh sel untuk pemindahan pada masa hadapan. Dalam kajian ini, keupayaan sel epitelium pernafasan (RECS) dan fibroblas hidung (NFs) daripada kedua-dua turbinat untuk membezakan sel-sel seketurunan saraf (NL) telah dibandingkan. Enam sampel MT dan IT manusia yang berlebihan daripada pasca pembedahan sinus telah dicerna dan sel-sel yang diperoleh dikultur. RECs dan NFs dipisahkan dan diaruh dengan faktor neurotropik, iaitu forskolin, faktor pertumbuhan fibroblas asas manusia, faktor pertumbuhan yang diperoleh daripada platelet dan domain heregulin- $\beta 1$-EGF. Berdasarkan imunositokimia dan tindak balas berantai polimerase kuantitatif, NL disebabkan MT yang diaruh mengekspreskan GFAP, Nestin dan reseptor P75. Pengaruhan NL menyebabkan RECS daripada MT dan IT mengekspreskan GFAP dan Nestin tetapi tidak mengekspreskan protein reseptor P75. RECS dan NFs yang tidak teraruh sebagai kawalan hanya mengekspreskan Nestin. Kajian ini menunjukkan bahawa sel mukosa hidung daripada kedua-dua IT dan MT mampu diaruh kepada sel-sel seketurunan saraf walaupun fibroblas MT didapati lebih sesuai daripada segi kualiti. Diharapkan tisu-tisu ini dapat memberikan kawasan penderma yang lebih baik dengan kurang morbiditi untuk transplantasi autologus atau alograf dalam perubatan regeneratif saraf pada masa depan.

Kata kunci: Aruhan saraf; mukosa pernafasan; seketurunan saraf; sel epitelium hidung; turbinat

\section{INTRODUCTION}

Human nasal mucosa plays a vital role in humidifying and filtering the air that we breathe in by producing mucous that trap pathogens and other unwanted particles. Nasal mucosa and innate immune system served as the first line of defence to protect the host against pathogen and infection (Lane 2009). The epithelial cells and fibroblast of nasal mucosa release various pro-inflammatory chemokines and cytokines, such as interleukin (IL) - 4, IL-6, IL - 8, IL- $1 \beta$, transforming growth factor (TGF)- $\beta 1$, monocyte chemoattractant protein-4 (MCP-4) and C-C motif chemokine-11 (CCL11), in response to the assault by the inhaled pathogens and toxins to modulate the innate and acquired immune responses (Ball et al. 2016; Dong Chang et al. 2018; Jae et al. 2019).

Since the development of tissue engineering and stem cell therapy, nasal mucosa has become an important source of cells for airway epithelium and tracheal reconstruction. Respiratory epithelial cells (RECs), nasal fibroblasts (NFs) and stem cells have been successfully isolated from nasal mucosa, especially from nasal turbinates (Hauser et al. 2011; Mohd Heikal et al. 2014; Nur Adelina et al. 2007; 
Ruszymah et al. 2011). The RECs has been reported to display stem cell properties through the expression of stem cell markers such as Frizzled-9, bone marrow stromal cell antigen-1, CD73, CD90 and CD105, even after serial passaging for up to passage 4 (Ruszymah et al. 2011). Previously, cells from nasal mucosa of the turbinate have been successfully used to develop an autologous tissueengineered trachea that can be transplanted into sheep. It was found that the transplanted cells promoted natural regeneration of the tracheal epithelium with minimal fibrosis (Mohd Heikal et al. 2010; Ruszymah et al. 2014). Nasal mucosa in the olfactory area is well known to contain olfactory ensheathing cells (OECs). OECs are specialised cells that support the neurogenesis and rejuvenation of the olfactory receptor neurons (Au \& Roskams 2002). OECs were also evidenced to support the remyelination process of demyelinated axons (Kato et al. 2000). Several studies, including clinical trials, were done using OECs to treat nerve damage and diseases ranging from spinal cord injury, peripheral nerve injury to Alzheimer's disease (Bing Chang et al. 2012; Lima et al. 2010; Lokanathan et al. 2014; Tan et al. 2013). Furthermore, human neural crest-derived stem cells have been isolated from inferior turbinates (Hauser et al. 2011). These cells were reported to be multipotent and able to improve the functional outcome of rats with neurological and psychiatric diseases (Müller et al. 2015). A study by Goldstein et al. (2013) showed that mesenchymal-like stem cells (MSC) isolated from lamina propria of nasal turbinates and septum have the capability to form neurosphere and expressed CD90, CD105, STRO-1, and nestin. They are able to transform into neuronal-like cells under differentiation conditions. To the best of our knowledge, there is no current study focusing on the quality and quantity of neural cells elements in the different part of human turbinates. Additionally, the neuronal differentiation potential of human nasal respiratory mucosa cells from the nasal turbinate has never been explored previously.

In this study, the neurogenic differentiation of human nasal mucosa cells obtained from the middle and inferior turbinate was evaluated. The present study aimed to compare the neurodifferentiation potential between the respiratory epithelial cells (RECs) and nasal fibroblasts (NFs) obtained from different parts of the nasal turbinate. Neuronal induction of human nasal turbinate cells has the potential application in the spiral ganglion neurons or cochlear nerve repair, by either directly replacing the neurons or via paracrine activation of the endogenous cells to do so (Bas et al. 2013; Mingliang et al. 2018). Currently, sensorineural hearing loss is on an increasing trend and affects an estimated five to 20 per 100,000 persons per year (Lin et al. 2012; Rabinowitz et al. 2006). Loss of receptor hair cells or spiral ganglion neurons, due to viral infection, vascular impairment, immune-mediated mechanisms, and inner ear and central nervous system abnormalities, were the cause of sensorineural hearing impairment (Lin et al. 2012). Repairing or restoring the damaged inner ear tissue remains a major challenge. Cochlear implantation surgery is the mainstay of treatment to restore input for those with profound sensorineural hearing loss that is not benefiting from conventional hearing-aid amplification. However, intact spiral ganglion neurons and cochlear nerve are required for cochlear implantation. Other treatment strategies to replace the defect of the nerve or loss of the spiral ganglion neurons are therefore needed and cell therapy can be an option to replace the damaged spiral ganglion neurons (Bas et al. 2013).

\section{MATERIALS AND METHODS}

ISOLATION AND CULTURE OF HUMAN RESPIRATORY NASAL EPITHELIAL CELLS (RECs) AND NASAL FIBROBLASTS (NFs)

Individual consents were obtained prior to the procedure with approval from the Institutional Ethics Committee (KPJ Healthcare University College: KPJUC/ORL/EC/2014/02). Human tissue samples derived from the lateral lamellar of the middle turbinate and the inferior portion of inferior nasal turbinate were obtained from six patients undergoing endoscopic sinus surgery and turbinoplasty. The redundant samples were taken from the donors with the age between 15-60 years.

The turbinate was cleaned by washing it several times with Dulbecco's Phosphate-Buffered Saline (DPBS) and was minced into small pieces. It was then digested using $0.6 \%$ collagenase type I solutions (Worthington, USA) for $1-2 \mathrm{~h}$ in an incubator shaker at $37^{\circ} \mathrm{C}$. Digested tissue containing NFs and RECs was centrifuged and the pellet was resuspended in co-culture medium (Bronchial Epithelial Cell Growth Medium (BEGM; Lonza, USA), Defined Keratinocyte Serum-Free Medium (DKSFM; Gibco, USA), F-12, and Dulbecco's Modified Eagle's Medium (DMEM; Biowest, USA) with the 1:1:2 ratio, supplemented with $5 \%$ fetal bovine serum (FBS) (Gibco, USA)) and seeded into a six-well plate. The cells were cultured at $37^{\circ} \mathrm{C}$ in $5 \% \mathrm{CO}_{2}$ incubator with culture medium being replaced every two to three days. Once the cells reached $80-90 \%$ confluency, in about five to seven days, NFs were differentially trypsinised using $0.05 \%$ Trypsin-EDTA (Lonza, USA) to separate them from RECs. The remaining RECs were supplemented with DKSFM and passaged up to two times. Meanwhile, NFs were cultured in F-12 and DMEM with 1:1 ratio, supplemented with $10 \%$ FBS. Once the cell reached $80-90 \%$ confluency, they were washed with DPBS and trypsinised using TrypLE ${ }^{\mathrm{TM}}$ Select (Gibco, USA) and counted with haemocytometer before being used for neurogenic induction.

\section{NEUROGENIC INDUCTION OF HUMAN NASAL TURBINATES}

The neurogenic induction was adapted from Nur Hidayah et al. (2012). The cells were incubated in Alpha-Minimum Essential Medium ( $\alpha$-MEM) containing $1 \mathrm{mM} \beta$-mercaptoethanol ( $\beta \mathrm{ME}$ ) without serum for $24 \mathrm{~h}$. The culture medium was replaced with differentiation medium consisting of $\alpha$-MEM containing $10 \%$ FBS and $35 \mathrm{ng} / \mathrm{mL}$ all-trans-retinoic acid (ATRA). Three days later, 
cells were transferred to $\alpha$-MEM containing $10 \%$ FBS and trophic factors $(5 \mu \mathrm{M}$ forskolin, $10 \mathrm{ng} / \mathrm{mL}$ recombinant human basic fibroblast growth factor (bFGF), $5 \mathrm{ng} / \mathrm{mL}$ platelet-derived growth factor-AA (PDGF-AA) and 200 $\mathrm{ng} / \mathrm{mL}$ heregulin- $\beta 1$-EGF-domain) and cultured for an additional four to five days before they were ready for in vitro evaluation. Cell morphology was observed and recorded using an inverted microscope. Total cell count and cell viability (induced and non-induced cells) were calculated by counting the cell after trypsinization using haemocytometer.

\section{EVALUATION OF NEURONAL CELL SURFACE MARKERS EXPRESSION}

Both induced and non-induced cells were evaluated by immunocytochemistry (ICC) and quantitative real-time PCR (qPCR) analysis. ICC was performed as previously described by Rabiatul et al. (2015). Briefly, the cells were probed with the following primary antibodies: polyclonal anti-S100b (mouse; 1:4,000; Becton Dickinson (BD), USA), monoclonal anti-Nerve Growth Factor (NGF) P75 receptor (mouse; 1:500; Chemicon Corp., Japan), monoclonal anti-Nestin (mouse; 1:500; BD) and monoclonal antiGlial Fibrillary Acidic Protein (GFAP) (rabbit; 1:100; Chemicon Corp., Japan) and tagged with the secondary antibody, Alexa Fluor 488 anti-mouse IgG (goat; 1:50; Life Technologies, USA), or Alexa Fluor 488 anti-rabbit IgG (goat; 1:50; Life Technologies, USA). Nuclei were counterstained with DAPI (Life Technologies, USA). Cells were examined using a fluorescence microscope (Eclipse Ti, Nikon, Japan) immediately after the staining procedure. For qPCR analysis, non-induced and induced RECs and NFs were trypsinised and the RNA was extracted from the cells using RNeasy Mini Kit (Qiagen, Germany) according to the manufacturer's protocol. The gene expression of Nestin as neural progenitor cell marker, S100, GFAP and P75NGF as Schwann cell markers on the RECs and NFs of both the MT and IT of the non-induced samples and induced samples were examined using the primers listed in Table 1. The qPCR was performed using $\mathrm{iQ}^{\mathrm{TM}}$ SYBR ${ }^{\mathrm{T}}$ Green Supermix (BioRad, USA) on Bio-Rad iCycler with MyiQ Optical Module thermal cycler.

Each qPCR reaction was performed with $1 \mu \mathrm{L}$ forward primer, $1 \mu \mathrm{L}$ reverse primer, $2 \mu \mathrm{L}$ cDNA template, 12.5 $\mu \mathrm{L}$ of iQ SYBR green supermix (Bio-Rad, USA) and 9.5 $\mu \mathrm{L}$ Nuclease free water in $25 \mu \mathrm{L}$ of total volume. Each reaction was done in triplicate. PCR amplifications included the following cycling conditions: one cycle at $95^{\circ} \mathrm{C}(3$ $\mathrm{min})$, followed by 40 cycles of denaturation at $95^{\circ} \mathrm{C}(30$ $\mathrm{s}$ ), annealing and extension at $55^{\circ} \mathrm{C}$ for $45 \mathrm{~s}$. Finally, melt curve analyses were done by heating the PCR mixtures from $65^{\circ} \mathrm{C}$ to $95^{\circ} \mathrm{C}$ in increments of $0.5^{\circ} \mathrm{C}$ every $5 \mathrm{~s}$ with simultaneous measurements. The data were analysed using iQ5 optical system software (Bio-Rad, USA).

\section{STATISTICAL ANALYSIS}

SPSS version 16 (SPSS Inc. USA) was used for data analysis. The comparison of the mean of total cell count viability between induced and non-induced groups of RECs and NFs were assessed with Student's paired t-test.

The qPCR data were presented as mean \pm standard deviation (SD). ANOVA test was used to determine the statistical significance of qPCR data. A $p$-value $<0.05$ was considered significantly different.

\section{RESULTS}

\section{CELLULAR MORPHOLOGY OF NON-INDUCED AND INDUCED} HUMAN NASAL MUCOSA CELLS

Phase-contrast microscopic observation showed the morphological changes of human nasal mucosa cells before and after induction. Following $24 \mathrm{~h}$ of induction, the non-induced RECs looked relatively similar to the induced RECs where they had a prominent non-uniform polygonal shape (Figure 1). On day three of post-induction, the non-induced RECs became more confluent compared to the induced RECs and remained symmetrical, whereas the induced RECs became more asymmetrical in shape and appeared to be apoptotic. One-week post completion of induction with neurogenic induction medium, the noninduced RECs continued to appear matured and confluent. Apoptotic morphological changes were observed in the induced RECs (Figure 1).

Initial culturing of nasal fibroblast cells showed no difference (Figure 1). Proliferation was observed in noninduced NFs upon day ten post-infection with elongated cytoplasmic extension. The induced NFs showed neuronal changes, where they exhibited a longer spindle-shaped fibroblastic morphology.

\section{VIABILITY ANALYSIS}

There is no significant difference observed in the total viable cell analysis between non-induced and induced

TABLE 1. List of primer used for qPCR analysis (5' -3')

\begin{tabular}{cll}
\hline Target gene & \multicolumn{1}{c}{ Forward primer } & \multicolumn{1}{c}{ Reverse primer } \\
\hline GFAP & GTGGGCAGGTGGGAGCTTGAT TCT & CTG GGGCGGCCTGGTATGACA \\
Nestin & AGAGGGGAATTCCTGGAG & CTGAGGACCAGGACTCTCTA \\
S100B & ATGTCTGAGCTGGAGAAGG & CTGTCTGCTTTCTTGCATG \\
P75 & CCTACGGCTACTACCAGGATGAG & TGGCCTCGTCGGAATACG \\
\hline
\end{tabular}



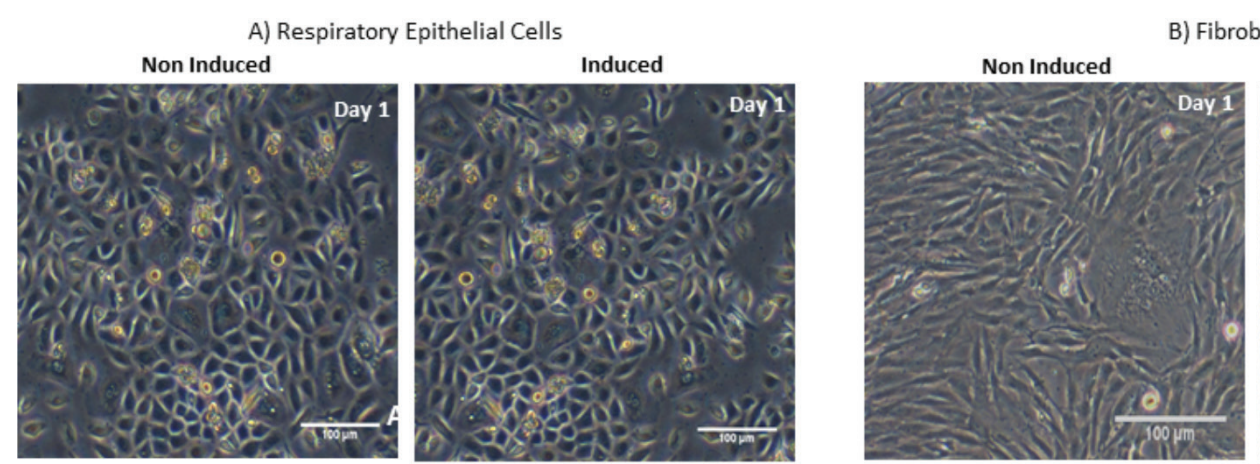

Fibroblasts
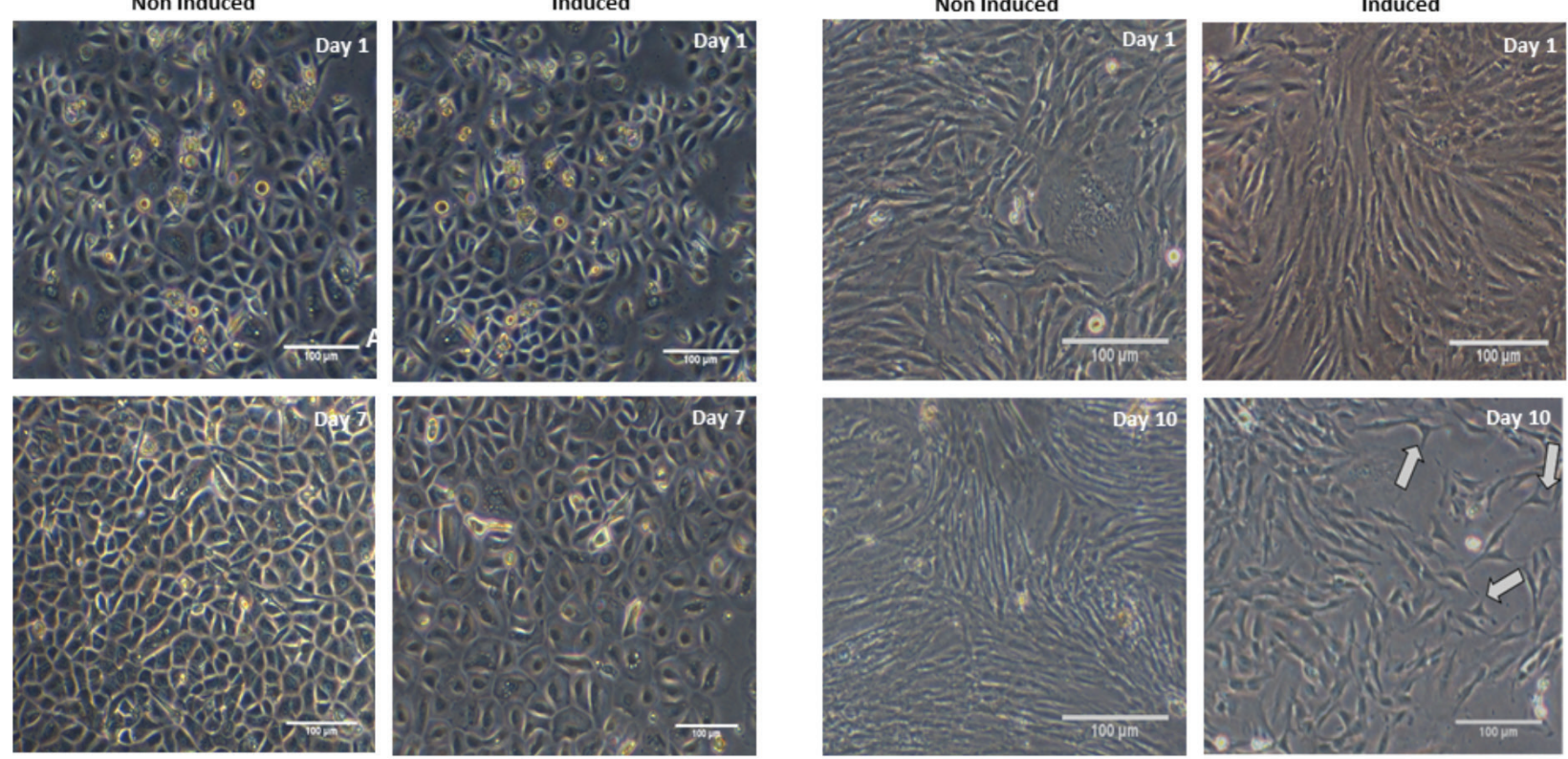

FIGURE 1. A) Morphology REC on day one and day seven, B) Morphology of fibroblast on day one and day ten. The induced NFs exhibited a longer spindle-shaped fibroblastic morphology (as shown by arrow) (40× magnification)

human nasal mucosa cells. The number of viable noninduced cells was higher compared to induced cells after one week (Figure 2). However, the difference was not statistically significant $(p>0.05)$. The percentage of viable cells also showed the same trend, whereas the non-induced RECs and NFs had a higher percentage of viable cells compared to their induced counterparts, both for middle turbinate and inferior turbinate, however, the differences were not statistically significant (data not shown).

\section{QUANTITATIVE ANALYSIS OF NON-INDUCED AND INDUCED HUMAN NASAL MUCOSA CELLS}

The RT-PCR analysis showed statistically-significant upregulation for GFAP and Nestin genes in induced RECs compared to its respective control $(p<0.05)$. In terms of S100B and P75NGFR, upregulations were observed but insignificant (Figure 3). In terms of tissue origin, the expression of GFAP and Nestin genes were significantly higher in induced RECs of MT compared to that of IT $(p<0.05)$. However, no significant difference was observed in the expression of S100 and P75NGF between MT and IT. Next, comparison of NFs' gene expression among MT and IT derived cells showed upregulation of all neural gene markers for the induced NFs of MT and IT compared to their respective control (Figure 3 ). However, only upregulation of GFAP, Nestin and P75 in the NFs of MT were statistically significant $(p<0.05)$. The gene upregulations in induced NFs of IT were insignificant. Finally, in terms of tissue origin, the expression of GFAP, Nestin and P75NGFR were significantly superior in NFs of MT $(p<0.05)$, but not significant for the expression of $\mathrm{S} 100 \mathrm{~B}(p>0.05)$.

\section{IMMUNOCYTOCHEMISTRY ANALYSIS OF SPECIFIC MARKERS PROTEIN EXPRESSION IN RECS AND NFS}

Induced RECs were positive for neuronal cell markers such as GFAP and Nestin but negative for S100B and P75NGF
Respiratory Epithelial Cells

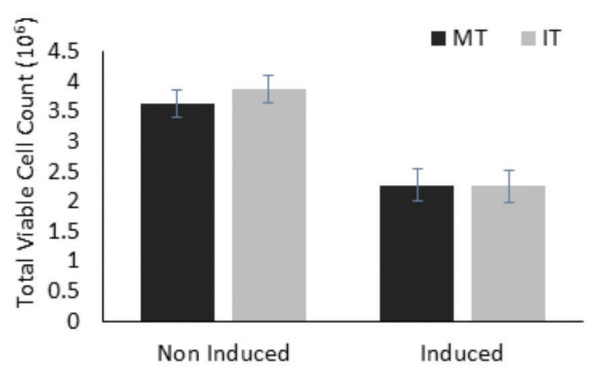

Fibroblasts

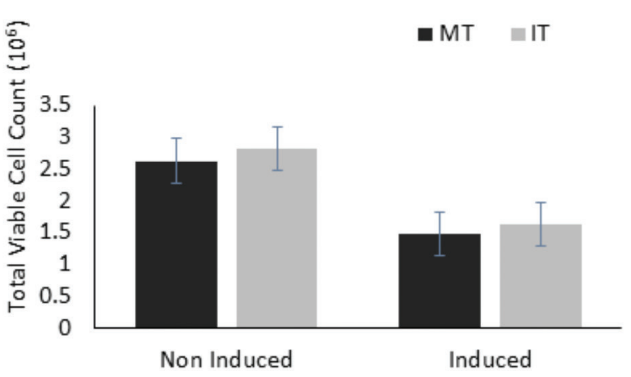

FIGURE 2. Total viable cell count for respiratory epithelial cells and nasal fibroblasts during the second subculture (P2) for noninduced and induced samples $(\mathrm{n}=6)$. There were no significant differences between the non-induced and induced samples 
A) Respiratory Epithelial Cells

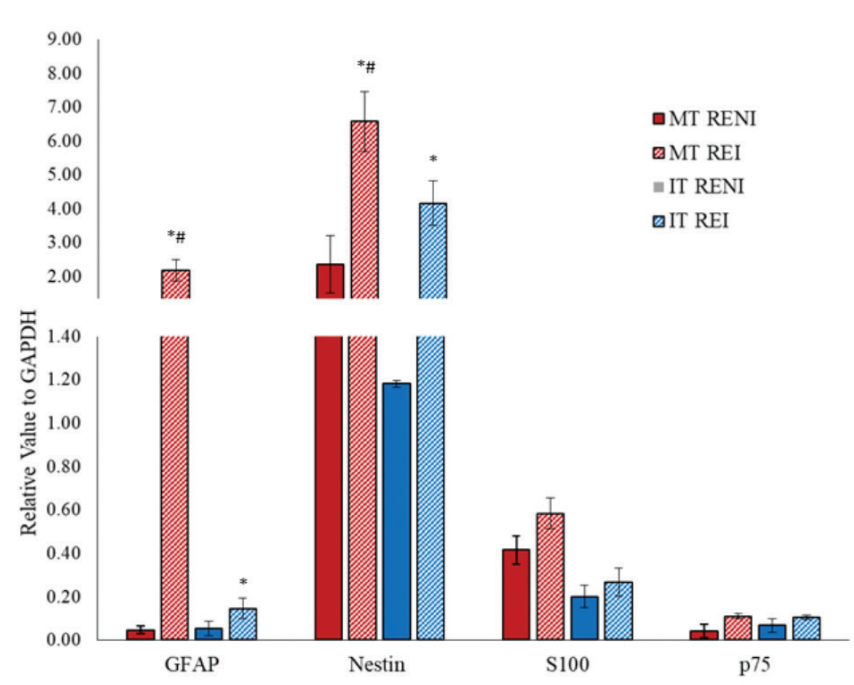

B) Fibroblasts

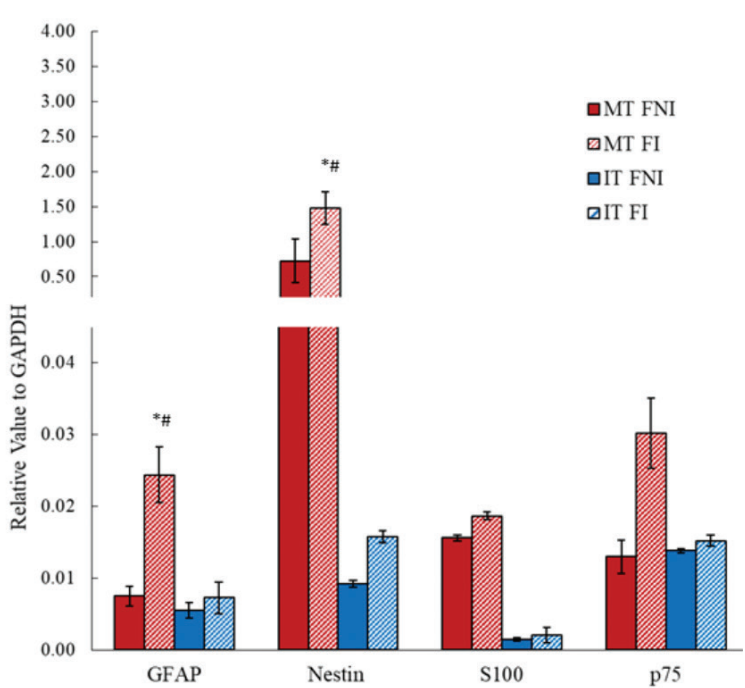

FIGURE 3. A) Quantitative PCR in RECs with four neural gene markers. MT RENI = non-induced RECs of MT; MT REI = induced RECs of MT; IT RENI = non-induced RECs of IT; IT REI = induced RECs of IT; $* P<0.05$ compared to non-induced RECs of the same turbinate; \# $P<0.05$ compared to induced RECs of the other turbinate, B) Quantitative PCR in NFs with four neural gene markers. MT FNI = non-induced Fibroblasts of MT; MT FI = induced Fibroblasts of MT; IT FNI = non-induced Fibroblasts of IT; IT FI = induced Fibroblasts of IT; * $P<0.05$ compared to non-induced fibroblasts of the same turbinate; $\# P<0.05$ compared to induced fibroblasts of the other turbinate

(Figure 4). However, Nestin was expressed in all the tested cell groups, regardless of the induced or non-induced cell (Figures $4 \& 5$ ). The induced NFs of MT showed positive expression for GFAP, P75NGF and Nestin while the induced NFs of IT showed positive expression for Nestin only (Figure 5).

\section{DISCUSSION}

Neurogenic differentiation of human nasal mucosa cells has been reported in earlier studies (Xingjia et al. 2013; Yang et al. 2017). These studies mainly focused on the isolation of olfactory epithelial-derived progenitors from rodent and human and their differentiation into neural lineage cells (Delorme et al. 2009; Meng et al. 2012; Murrell et al. 2008; Zhang et al. 2006). This study aimed to determine the quality and quantity of the RECs and NFs derived from the MT and IT, with a focus on their induction to neural lineage cells for future tissue engineering purposes. It was found that the human nasal mucosa cells from both MT and IT can undergo neurogenic differentiation, but there were differences in terms of quality and quantity of the neurodifferentiated cells.

In term of cell viability, there were no statistical differences between induced RECs of MT and induced RECs of IT as well as induced NFs in MT and IT. However, high variability was observed in the total number of cells cultured per $\mathrm{cm}^{2}$ from sample to sample. This could be attributed to the size of the cultured turbinate and the number of REC colonies per plate as it is well known that prolonged culturing might compromise subsequent growth (Fulcher \& Randell 2013). Due to sample variation, RECs from some samples took a longer time to achieve the desired confluency compared to others. NFs had a higher proliferative rate at all passage compared to RECs. This may be due to the ability of NFs to secrete various cytokines and growth factors to maintain its stability (Ball et al. 2016).

Generally, the presence of trophic factors in the culture medium will increase the cell proliferation rate and viability of the induced cells. Contradictorily, lower number of viable cells were observed in our induced NF and REC compared to their non-induced counterparts. This was due to the addition of BME at the pre-induction stage that reduces the number of viable cells drastically before the trophic factors were supplemented.

Morphology of the non-induced RECs and noninduced NFs only start to show more obvious differences as compared to the induced RECs and NFs after one-week post completion of induction with neurogenic induction medium. We hypothesized that the morphology results presented in this study using the induction mediums adapted from Nur Hidayah et al. (2012) may not be an optimal medium for human nasal turbinates. Further studies need to be done to ensure the appropriate induction medium specific for human nasal turbinates are used to demonstrate the ability of adult human nasal turbinates to undergo neurogenic differentiation for both middle turbinate and inferior turbinates.

All the induced and non-induced samples of RECs and NFs in our study demonstrated upregulation of all the tested markers at the gene level. Xingjia et al. (2013) showed that positive Nestin expression was seen in NFs of MT, but the expression was not tested in the OECs from the human MT. Another study by Hauser et al. (2011) also 


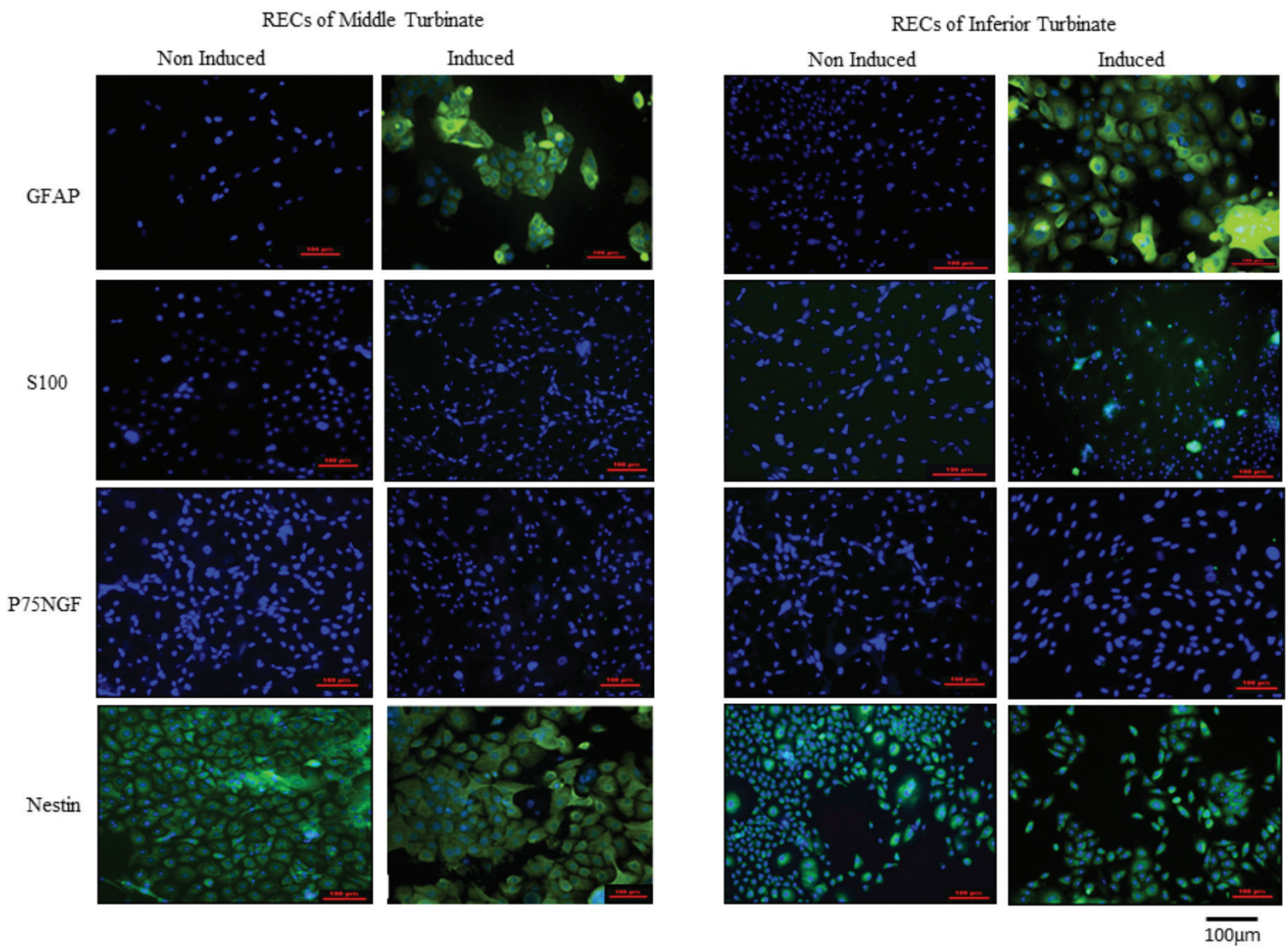

FIGURE 4. Immunocytochemical analysis of non-induced and induced RECs. GFAP (green), S100 (green), P75NGF (green), Nestin (green), nuclei (blue)

reported on the positive expression of Nestin marker in respiratory epithelial cell and neural crest-derived stem cell derived from adult human inferior turbinate. A recent study demonstrated that early passage of fibroblasts does contain cells that express Nestin but not Vimentin, a common specific marker for fibroblast. Thus, they hypothesised that these group of cells might be the multipotent stem cells of the human skin (Fang et al. 2017). Nestin expression was seen in both induced and non-induced samples in this study. Such findings were not surprising as it is present in neuroepithelial cells that may exist in both induced and non-induced proliferating nasal mucosa tissues. We believe that Nestin was not downregulated due to insufficient differentiation into a more matured stage, as supported by the lack of S100B expression in induced samples. S100 is known to indicate a late developmental stage whereby the GFAP-expressing cells lose their neural stem cell potential (Raponi et al. 2007).

GFAP marker was not detected in induced NFs of IT by ICC analysis. However, qPCR showed a notable upregulation of GFAP in induced NFs of IT compared to that of non-induced. One possible explanation could be that while qPCR can detect a minute amount of mRNA, the amount of protein translated might be insufficient for ICC detection.
Upregulation of S100B gene expression was observed in the qPCR analysis of all of the induced RECs and NFs of MT and IT, but they were not statistically significant $(p>0.05)$. In contrast, no expression of S100B was observed in any of the samples by ICC analysis. A possible explanation is that $\mathrm{S} 100 \mathrm{~B}$ tends to be expressed in cells at a more mature stage among the GFAP-positive cells. Expression of GFAP and Nestin in our samples indicates that only a minimal portion of the cultured cells achieved maturity, which explained the low expression of S100B. A similar observation was also reported by Raponi et al. (2007) in neural stem cells.

Although upregulation of P75 gene marker was observed in all induced samples for both RECs and NFs, they were not significant $(p<0.05)$, except for induced NFs of MT. The P75 protein was also not detected by ICC analysis in any of the groups. This suggests that the differentiation of our sample probably had achieved adequate differentiation towards Schwann cell lineage and thus were not expressing a significant amount of P75NGFR. However, Hauser et al. (2011) found that when sorted based on P75NGFR expression, both positive and negative fractions of the inferior turbinate cells were positive for Nestin expression and showed the ability to form neurospheres, despite positive fractions showed shorter population doubling 


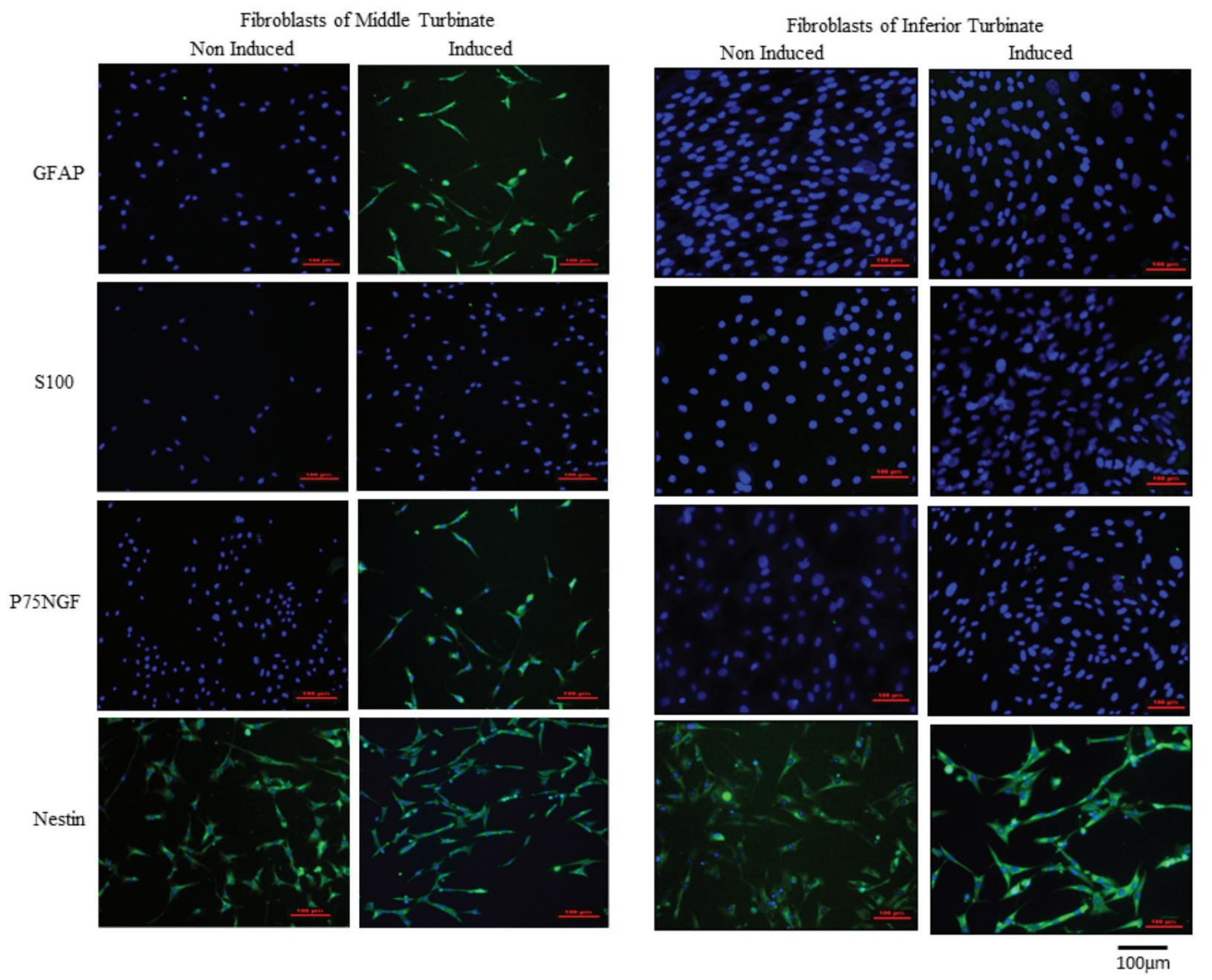

FIGURE 5. Immunocytochemical analysis of non-induced and induced NFs. GFAP (green),

S100 (green), P75NGF (green), Nestin (green), nuclei (blue)

time. This suggests that IT samples could still be used in neural stem cells induction even though they did not show significant P75NGFR upregulation.

The induction medium adapted from Nur Hidayah et al. (2012) protocol may not be optimal for neurogenic differentiation of the human nasal mucosa in this study. In addition, neurogenic induction medium containing $\beta$-mercapethanol can cause cells to undergo apoptosis besides acting as a pre-induction factor. Further studies need to be done to optimise the appropriate induction mediums specific for human nasal mucosa cells, which drive the neurogenic differentiation with higher efficiency for both middle turbinate and inferior turbinate.

The limitation of this study includes the variation in patient samples and also the small sample size. The variation in patient samples might cause sample bias, where the general population's tissue may behave slightly different from those of the diseased. However, it will be challenging to obtain nasal turbinate tissues from healthy humans. The insufficient sample number may mask any significant difference with the control, and the overall result may not correlate with the larger population. Thus, larger sample size and inclusion of healthy nasal turbinate tissues may provide a better indication of the ability to differentiate into neural lineage cells. Besides that, the spontaneous expression of Schwann cell markers such as Nestin, S100 and P75 in nasal mucosa cells and other cells (Hauser et al. 2011; Khairunnisa et al. 2019) may hinder the identification of cells that differentiated into neural lineage cells. Therefore, a functional assay is needed to validate a successful neurogenic differentiation.

\section{CONCLUSION}

Human nasal respiratory mucosa is indeed a potential autologous cell source, which is useful for future tissue engineering applications. In this study, the induced RECs and NFs showed neuronal appearance. The induced RECs expressed the neuron cell markers, namely GFAP and Nestin, while the induced MT NFs expressed GFAP, Nestin and P75NGFR. All the samples (regardless of non-induced or induced) expressed Nestin markers. These concluded that induced RECs and NFs of MT are of superior quality than those induced from IT. However, it must be recognised 
that cells from both the MT and IT have the capability for neurogenic differentiation. Given the advantages of ease and safety in harvesting IT compared to MT, IT is still a better donor tissue candidate than the MT. It is with great hope that this study can serve as a stepping stone for future studies on tissue engineering and regeneration for the neurogenic differentiation from the human nasal mucosa.

\section{ACKNOWLEDGEMENTS}

This work was funded by Universiti Kebangsaan Malaysia (UKM) (grant number DIP-2012-08 and AP 2013-015). The author(s) declare that they have no competing interests.

\section{REFERENCES}

Au, E. \& Roskams, A.J. 2002. Culturing olfactory ensheathing glia from the mouse olfactory epithelium. In Neural Stem Cells: Methods and Protocols. Methods in Molecular Biology, Volume 198, edited by Zigova, T., Sanberg, P.R. \& SanchezRamos, J.R. Totowa: Humana Press.

Ball, S.L., Mann, D.A., Wilson, J.A. \& Fisher, A.J. 2016. The role of the fibroblast in inflammatory upper airway conditions. The American Journal of Pathology 186(2): 225-233.

Bas, E., Van De Water, T.R., Lumbreras, V., Rajguru, S., Goss, G., Hare, J.M. \& Goldstein, B.J. 2013. Adult human nasal mesenchymal-like stem cells restore cochlear spiral ganglion neurons after experimental lesion. Stem Cells and Development 23(5): 502-514.

Bing Cang Li, Chuan Xu, Jie Yuan Zhang, Yue Li \& Zhao Xia Duan. 2012. Differing Schwann cells and olfactory ensheathing cells behaviors, from interacting with astrocyte, produce similar improvements in contused rat spinal cord's motor function. Journal of Molecular Neuroscience 48(1): 35-44.

Delorme, B., Nivet, E., Gaillard, J., Häupl, T., Ringe, J., Devèze, A., Magnan, J., Sohier, J., Khrestchatisky, M. \& Roman, F.S. 2009. The human nose harbors a niche of olfactory ectomesenchymal stem cells displaying neurogenic and osteogenic properties. Stem Cells and Development 19(6): 853-866.

Dong Chang Lee, Hyunsu Choi, Jeong-Min Oh, Yupyo Hong, Su Hee Jeong, Choung Soo Kim, Dong-Kee Kim, WonKyung Cho, Sung Won Kim, Soo Whan Kim, Jin Hee Cho \& Joohyung Lee. 2018. The effect of urban particulate matter on cultured human nasal fibroblasts. International Forum of Allergy \& Rhinology 8(9): 993-1000.

Fang, F., Ni, K., Cai, Y., Ye, Z., Shang, J., Shen, S. \& Xiong, C. 2017. Biological characters of human dermal fibroblasts derived from foreskin of male infertile patients. Tissue and Cell 49(1): 56-63.

Fulcher, M.L. \& Randell, S.H. 2013. Human nasal and tracheobronchial respiratory epithelial cell culture. In Methods in Molecular Biology. New Jersey: Springer.

Goldstein, B.J., Hare, J.M., Lieberman, S. \& Casiano, R. 2013. Adult human nasal mesenchymal stem cells have an unexpected broad anatomic distribution. International Forum of Allergy \& Rhinology 3(7): 550-555.

Hauser, S., Widera, D., Qunneis, F., Müller, J., Zander, C., Greiner, J., Strauss, C., Lüningschrör, P., Heimann, P. \& Schwarze, H. 2011. Isolation of novel multipotent neural crest-derived stem cells from adult human inferior turbinate. Stem Cells and Development 21(5): 742-756.
Jae Woong Hwang, Jae Hyung Kim, Hyun Jung Kim, In Hak Choi, Hye Min Han, Ki Jung Lee, Tae Hoon Kim \& Sang Hag Lee 2019. Neutrophil extracellular traps in nasal secretions of patients with stable and exacerbated chronic rhinosinusitis and their contribution to induce chemokine secretion and strengthen the epithelial barrier. Clinical \& Experimental Allergy 49(10): 1306-1320. https://doi. org/10.1111/cea.13448.

Kato, T., Honmou, O., Uede, T., Hashi, K. \& Kocsis, J.D. 2000. Transplantation of human olfactory ensheathing cells elicits remyelination of demyelinated rat spinal cord. Glia 30(3): 209-218.

Khairunnisa Ramli, Ifasha Aminath Gasim, Amir Adham Ahmad, Shariful Hassan, Zhe Kang Law, Geok Chin Tan, Azmi Baharuddin, Amaramalar Selvi Naicker, Ohnmar Htwe \& Nor Hazla Mohammed Haflah. 2019. Human bone marrowDerived MSCs spontaneously express specific Schwann cell markers. Cell Biology International 43(3): 233-252.

Lane,A.P. 2009. The role of innate immunity in the pathogenesis of chronic rhinosinusitis. Current Allergy and Asthma Reports 9(3): 205-212.

Lima, C., Escada, P., Pratas-Vital, J., Branco, C., Arcangeli, C.A., Lazzeri, G., Maia, C.A.S., Capucho, C., Hasse-Ferreira, A. \& Peduzzi, J.D. 2010. Olfactory mucosal autografts and rehabilitation for chronic traumatic spinal cord injury. Neurorehabilitation and Neural Repair 24(1): 10-22.

Lin, R.J., Krall, R., Westerberg, B.D., Chadha, N.K. \& Chau, J.K. 2012. Systematic review and meta-analysis of the risk factors for sudden sensorineural hearing loss in adults. The Laryngoscope 122(3): 624-635.

Lokanathan Yogeswaran, Min-Hwei Ng, Shariful Hasan, Anuar Ali, Mazzre Mahmod, Ohnmar Htwe, Sharifah Ahmad Roohi, Ruszymah Hj Idrus, Shalimar Abdullah \& Amaramalar Selvi Naicker. 2014. Olfactory ensheathing cells seeded muscle-stuffed vein as nerve conduit for peripheral nerve repair: A nerve conduction study. Journal of Bioscience and Bioengineering 118(2): 231-234.

Meng Wang, Lu Chengliang \& Fred Roisen. 2012. Adult human olfactory epithelial-Derived progenitors: A potential autologous source for cell-Based treatment for Parkinson's Disease. Stem Cells Translational Medicine 1(6): 492-502.

Mingliang Tang, Xiaoqian Yan, Qilin Tang, Rongrong Guo, Peng Da \& Dan Li. 2018. Potential application of electrical stimulation in stem cell-based treatment against hearing loss. Neural Plasticity 2018: 9506387.

Mohd Heikal Mohd Yunus, Kan Chan Siang, Nurul Izzati Hashim, Ng Pei Zhi, Nur Fathurah Zamani, Primuharsa Putra Sabri, Mohd Fauzi Busra, Shiplu Roy Chowdhury \& Ruszymah Haji Idrus. 2014. The effects of human serum to the morphology, proliferation and gene expression level of the respiratory epithelium in vitro. Tissue and Cell 46(4): 233-240.

Mohd Heikal, M.Y., Aminuddin, B.S., Jeevanan, J., Chen, H.C., Sharifah, S.H. \& Ruszymah, B.H.I. 2010. Autologous implantation of bilayered tissue-engineered respiratory epithelium for tracheal mucosal regenesis in a sheep model. Cells Tissues Organs 192(5): 292-302.

Müller, J., Ossig, C., Greiner, J.F.W., Hauser, S., Fauser, M., Widera, D., Kaltschmidt, C., Storch, A. \& Kaltschmidt, B. 2015. Intrastriatal transplantation of adult human neural crest-derived stem cells improves functional outcome in parkinsonian rats. Stem Cells Translational Medicine 4(1): 31-43. 
Murrell, W., Wetzig, A., Donnellan, M., Féron, F., Burne, T., Meedeniya, A., Kesby, J., Bianco, J., Perry, C. \& Silburn, P. 2008. Olfactory mucosa is a potential source for autologous stem cell therapy for Parkinson's disease. Stem Cells 26(8): 2183-2192.

Nur Adelina Ahmad Noruddin, Aminuddin B Saim, Kien Hui Chua \& Ruszymah Idrus. 2007. Human nasal turbinates as a viable source of respiratory epithelial cells using coculture system versus dispase dissociation technique. The Laryngoscope 117(12): 2139-2145.

Nur Hidayah Hassan, Ahmad Fadzli Sulong, Min-Hwei Ng, Ohnmar Htwe, Ruszymah Idrus, Sharifah Ahmad Roohi, Amaramalar Selvi Naicker \& Shalimar Abdullah. 2012. Neural-differentiated mesenchymal stem cells incorporated into muscle stuffed vein scaffold forms a stable living nerve conduit. Journal of Orthopaedic Research 30(10): 16741681 .

Rabiatul, A.R., Lokanathan, Y., Rohaina, C.M., Chowdhury Shiplu Roy, Aminuddin, B.S. \& Ruszymah, B.H.I. 2015. Surface modification of electrospun poly (methyl methacrylate)(PMMA) nanofibers for the development of in vitro respiratory epithelium model. Journal of Biomaterials Science, Polymer Edition 26(17): 1297-1311.

Rabinowitz, P.M., Slade, M.D., Galusha, D., Dixon-Ernst, C. \& Cullen, M.R. 2006. Trends in the prevalence of hearing loss among young adults entering an industrial workforce 1985 to 2004. Ear and Hearing 27(4): 369-375.

Raponi, E., Agenes, F., Delphin, C., Assard, N., Baudier, J., Legraverend, C. \& Deloulme, J.C. 2007. S100B expression defines a state in which GFAP-Expressing cells lose their neural stem cell potential and acquire a more mature developmental stage. Glia 55(2): 165-177.

Ruszymah Idrus, Nur Adelina, Ahmad Noruddin, Chen Hui Cheng, Yogeswaran Lokanathan \& Aminuddin Bin Saim. 2014. Titanium mesh with expanded respiratory epithelial cells in tracheal reconstruction. Journal of Biomaterials and Tissue Engineering 4(5): 367-372.

Ruszymah, B., Izham, B.A., Heikal, M.M., Khor, S.F., Fauzi, M.B.\& Aminuddin, B.S. 2011. Human respiratory epithelial cells from nasal turbinate expressed stem cell genes even after serial passaging. Medical Journal of Malaysia 66(5): 440-442.

Tan, C.W., Ng, M.H., Ohnmar, H., Lokanathan, Y., Nur-Hidayah, H., Roohi, S.A., Ruszymah, B.H.I., Nor-Hazla, M.H., Shalimar, A. \& Amaramalar, S.N. 2013. Sciatic nerve repair with tissue engineered nerve: Olfactory ensheathing cells seeded poly (lactic-co-glygolic acid) conduit in an animal model. Indian Journal of Orthopaedics 47(6): 547-552.
Xiaodong Zhang, Kathleen M Klueber, Zhanfang Guo, Jun Cai, Chengliang Lu, Welby I Winstead, Mengsheng Qiu \& Fred J Roisen 2006. Induction of neuronal differentiation of adult human olfactory neuroepithelial-derived progenitors. Brain Research 1073-1074: 109-119.

Xingjia Wu, William E Bolger \& Juanita J. Anders. 2013. Fibroblasts isolated from human middle turbinate mucosa cause neural progenitor cells to differentiate into glial lineage cells. PLoS ONE 8(10): e76926.

Yang Li, Ying Sheng, Jian Min Liang, Xiao Yong Ren \& Yan Cheng. 2017. Glial differentiation of human inferior turbinate-derived stem cells: A new source of cells for nerve repair. NeuroReport 28(5): 235-241.

Tan Shi Nee \& Aminuddin Saim

KPJ Healthcare University College

71800 Nilai, Negeri Sembilan Darul Khusus

Malaysia

Yogeswaran Lokanathan \& Rohaina Che Man

Tissue Engineering Centre

Universiti Kebangsaan Malaysia

56000 Kuala Lumpur, Federal Territory

Malaysia

Aminuddin Saim

Ear, Nose and Throat Consultant Clinic

Ampang Puteri Specialist Hospital

68000 Ampang, Selangor Darul Ehsan

Malaysia

Ruszymah Bt Hj Idrus*

Department of Physiology

Faculty of Medicine

Universiti Kebangsaan Malaysia

56000 Kuala Lumpur, Federal Territory

Malaysia

*Corresponding author; email: ruszyidrus@gmail.com

Received: 8 June 2018

Accepted: 15 August 2019 